\title{
ASEAN-INDOCHINA DIPLOMACY, 1975-1982
}

by

\author{
K.K. Nair*
}

The foreign policy interests of eleven political actors have influenced to varying degrees the shape and management of regional order in Southeast Asia following the climatic events of 1975: two Indochinese states in conflict with a third, the original five (now six) ASEAN states acting in concert but divided internally in their perceptions of the scenario, and three extra-regional powers with different but vital stakes in the strategic environment of Southeast Asia.

In addressing the differences between ASEAN and Indochinese states in the efforts to arrive at a mutually acceptable framework for order in Southeast Asia, the critical variable is naturally the nature of the differences between Vietnam and China. Ever since the defeat of the United States in Vietnam, Hanoi has perceived China to be the main regional adversary. In 1978, at the fourth plenum of the Central Committee of the Vietnamese Communist Party, Le Duan declared that Chinese "reactionaries" in collusion with the United States were waging a sabotage war against Vietnam on the military, political, economic and cultural fronts to isolate the country in the international arena. The Vietnamese fear that their national security is being undermined by the threat posed by the Chinese at their northern borders, espionage warfare and the sowing of divisions among the various ethnic groups and between the people and the Vietnamese Communist Party. Since the Chinese threat is perceived to be not only real but also no different from the French,

- The writer was author of a recently published study entitled ASEAN-INDOCHINA COL POLITICS OF ACCOMMODATION (Canberra: Strategic and Defence Studies Center. Australia National University, 1984) $2^{29} 1_{11}$ 
Japanese and American threats in earlier periods, Vietnam sees its security in a regional alliance between it and the two other Indochinese states, Laos and Kampuchea, and an international alliance with the Soviet Union as the leader of the world socialist community. The reference to history underlines the fundamental view of Indochina as a strategic theatre of battle for several decades.

The China factor in Vietnam's perceptions of its national security is relevant to Vietnam's relations with ASEAN. Though Vietnam has, from time to time, accused ASEAN of being an American-front organisation and as having been enticed by China to oppose what it sees as a necessary "revolution" in Laos and Kampuchea, it is doubtful that Vietnam intends to cause any political destabilisation of the ASEAN states. The thrust in Vietnam's policy towards ASEAN is two-fold: to keep the regional organisation diplomatically off balance and on the defensive by a deliberate ambivalence in Hanoi's policy announcements. In this way, Vietnam hopes that ASEAN states would keep the negotiations going for a political solution to the six year old Indochina crisis. The second thrust in Vietnam's policy towards ASEAN is to dissuade ASEAN states, in particular Thailand, from moving close to the Chinese camp. The first Vietnamese message on this score was in January 1980, following a hurried meeting of Indochinese foreign ministers, when ASEAN states were in effect told to choose between China and Vietnam, emphasising the danger for ASEAN of dependence upon the United States and China.

Apart from the difficulty in responding to the Vietnamese style of diplomacy, ASEAN states were also not agreed on their own perceptions of which power - Vietnam or China - posed the bigger threat to their security in the short and medium term; this meant that ASEAN policies were also not entirely free from their own ambiguities. ${ }^{1}$

'Diplomacy was often conducted at two levels: common denominator positions taken by ASEAN as a corporate body in the "regional" interests as it saw them, and those assumed by member states in accordance with "national" perceptions of the events as they unfolded. Thus, whilst a large measure of consensus was often reached between members to enable joint ASEAN diplomacy to be conducted, there were also occasions when certain member states preferred to work outside the formal framework of the organisation so as not to involve ASEAN in certain approaches. Also, given the differences between member states in their perceptions of external threats to regional security. 
Vietnam's attempt to shape the pattern of power in Indochina between 1975 and 1977 profoundly disturbed ASE $A N$ states which feared a unified Indochina emerging as a third temple of Communism. Hanoi's concern was essentially two-fold. The first concern was economic, namely, to resolve the problems of unemployment, urban population concentrations, the war ravaged economy and a million demobilised South Vietnamese soldiers. The other concern was the political task of consolidating the victory over South Vietnam and the formulation of appropriate measures to ensure the security of a united Vietnam. There are two sets of problems with regard to the management of Vietnam's security. One was to bring Kampuchea within the sphere of Vietnam's influence as had been achieved in the case of Laos. The second - which involved the ASEAN states - was to reduce the threat that Hanoi perceived in the residual American military presence in Thailand and the Philippines, states which had provided the launching pads for the American war effort in Vietnam.

Hanoi was resolute in its determination to see the 25,000 US military personnel in the four major airbases in Thailand evicted, not merely to remove a potential source of danger but also to punish Thailand for its previous collaboration against Vietnam. Hanoi's demands on Thailand coincided with an independent and vociferous public agitation within Thailand against the continuation of the American'military establishment. It can be argued that Vietnamese pressure was less important then the force of domestic public opinion, inflamed by the injudicious conduct of the Americans, in persuading a reluctant Thai government to call for American military withdrawal despite the protestation of the Thai Armed Forces. Once Thailand had effected its decision on the matter, it was Vietnam which took the lead to normalise relations with Thailand, and this was accomplished after some difficulty in August $1976 .^{2}$ The American military

it has not teen elear whether ASE.AN policy postures were designed with specific refierence to Indochina or whether some states treated the aftermath of Vietnam exclusively in terms of Sino-Soviet rivalry for influence in the region.

'Diplomatic relations were established between Thailand and Vietnam on 6 August 1976 on the basis of principles that had featured in Victnamese diplomatic relations with other ASEAN states. North Vietnam and Thailand took note of the problems that had been touched upon during the negotiations hut not entirely resolved. If llanoi's softened stand on some of these issues had helped Thailand. Hanoi still had the option to support Thai insurgents in the Thai Communist Party. Ilowever, the success of the 
presence in far away Philippines was considered to be less of a threat: Hanoi was content with the Marcos government's efforts to establish Philippine sovereignty over the Clark and Subic air and naval bases, and with Marcos's move towards an independent foreign policy posture. ${ }^{3}$

However, the lowering of the American military profile in Thailand and the Philippines and the normalisation of relations between Vietnam and the member states of ASEAN did not lead to a relaxation in the style of Vietnamese diplomacy. A distinction was drawn between, on one hand, recognition of and friendship with member states of ASEAN on a strictly bilateral basis and, on the other, a general distrust and nonrecognition of ASEAN as a multilateral organisation. Whether or not Vietnam genuinely believed that ASEAN was American inspired ${ }^{4}$ and serving American strategic interests in the region, Hanoi was not prepared to overlook the implications of the Manila Pact and the American nuclear shield represented by the Seventh Fleet.

\footnotetext{
Thai negotiating team received only a mixed reception in Bangkok: the right wing press criticised Thai Foreign Minister Pichai Rattakul and the Foreign Ministry for 'craw ling on its knees to the cnemy', Far Eastern Economic Review' (hereinafter referred to as FEER). 20 August 1976, 9. Thai Premier Seni Pramoj's initiatives however suffered reversals when his short-lived government was succeeded in October 1976 by that of the stridently anti-communist Thanin Kraivichien. And it was not until January 1978 that Thai-Vietnamese relations were once again normalised.

${ }^{3}$ Normalisation of Philippine-Vietnam relations did not occur overnight, even if those ties were opened up more quickly than expected during the visit of Phan Hien to Manila in July 1976. There had been an attempt to normalise relations between the tho countries in August 1975 but it proved abortive; contacts however had been maintained between them through their respective diplomatic missions in Algiers (FEER, 16 July 1976). 14. But the normalisation of Philippine-Vietnam relations on 12 July 1976 did proceed lar more smoothly than did Thai-Vietnamese normalisation in the following month.

IIJnoi's suspicions that the United States was using certain ASEAN states as part of a forward defence strategy in the area were heightened by expected increases in US nilitury sales to these states. In fact, in the 1975-76 period, Malaysian and Singaporean arms purchases from the US exceeded all previous levels. In the case of Malay sia, the figures for 1976 and 1977 were expected to increase ten-fold to US51 million, with another US28 million in planned cash purchases. Singapore, the only ASEAN state with no outright US military aid or sales credit, increased its cash purchases more than nine times to US22.6 million. Thailand and the Philippines, with US98.4 million and CS93.7 million. accounted for more than half of those cash and credit purchases by ASEAN: Indonesia received a grant aid worth US39 million to meet a variety of military demands (FEER, 23 July 1976. 28). Hanoi feared that the step up in nilitary oid. in one form of another, indicated collusion between the US and ASEAN states: the grounds for this helief were that, for the most part, the US military sakes were on terms that were highly concessionary and fexible.
} 
It served Vietnam's tactics to draw a distinction between the organisation and its member states. The 'double edged policy' through which Hanoi expressed itself to ASEAN ought not to be taken only at its face value. It served a number of purposes. By exercising the right to withhold recognition of ASEAN as a multilateral organisation whilst selectively cultivating cordiality with member states on a strictly bilateral basis, Hanoi achieved two goals. At the Indochina level it enabled Vietnam to maintain its revolutionary credibility by attacking ASEAN as an American frontline organisation. At the regional level it applied pressure on ASEAN states to take Hanoi's sensitivities into account and thereby limited the possibility of ASEAN leaning towards the 'imperialists' or forming a military pact.

In the period immediately after the victory over Saigon, Hanoi appeared enthusiastic for close neighbourly relations with the ASEAN states. To a considerable extent, this was intended to convince Washington that Vietnam was prepared to live in peace with its neighbours; such a gesture served to expedite the normalisation of Hanoi's relations with Washington - the prime foreign policy lever for the economic recovery of Vietnam. The major problem for Hanoi in this regard at that period was the coup in Thailand in the last quarter of 1976 which brought in the inflexible anti-communist Thanin Kraivichien as premier for a year. Even so Vietnam was fairly mild in its reaction to Thailand. $^{5}$

ASEAN was not quite certain in the period 1975 to 1978 how to respond to Vietnam's olive branch diplomacy. The dismantling of the American military presence in Thailand and the Philippines, the inadequacies of the Five Power Defence Arrangements for Malaysia and Singapore and the problem of communist insurrectionary movements were leading ASEAN states to review their foreign policies. Basically, this consisted

\footnotetext{
SOne reason that might account for the moderation in Hanoi's hostility towards ASEAN at this period is related to the difficulties that Vietnam was experiencing in its relations with Kampuchea and China. The fighting on the border with Kampuchea was escalating fast (BBC, Summory of World Broudcasts. FF/5711/A-3, 1-2) and IIanoi was anxious that its military operations not provoke a military response from Beijing. particularly as tension continued on the Vietnamese. Chinese horder. In the circumstances. Ilanoi": attention had turned from ASF.AN to Kampuchea and China: it made good sense. meanwhile to continue the process of seeking detente.
} 
of a shift from a 'defence' policy characterised by dependence upon a multilateral military structure to one of 'security' defined broadly to emphasise the value of national and regional resilience. Security was also perceived in terms of the necessity of reafliming $\triangle S E A N$ 's concept of a Zone of Peace, Freedom and Neutrality (which Vietnam had rejected), the normalisation of relations with the People's Republic of China (in the case of three $\triangle$ SEAN states) and accommodation with Vietnam as well as the two other Indochinese states.

However, within ASEAN there were divisions between one group, made up of Thailand and Singapore, which interpreted Vietnam's style of diplomacy as evidence of bellicosity and evil intentions. and the other group of states which felt that Vietnam could be placated. A division also existed between Malaysia. Thailand and the Philippines which saw the normalisation of relations with China as a productive counterweight to Vietnam and the other two which saw China as a greater long term threat. There were further differences between the styles of Thanin Kraivichien and those of other leaders who pursued rapproachement with Vietnam. Differences also existed between loyalty to Thailand as the frontline state and the sometimes divergent viewpoint of each state. Thus, ASEAN diplomatic initiatives towards regional detente with Vietnam were made up of several key elements. Whilst ASEAN did not want to acquiesce in Hanoi's ambitions (or Soviet plans) ${ }^{6}$ to shape the regional order in Southeast Asia, the member states remained divided over how best to handle the situation without provoking Hanoi's wrath.

"The Soviet Union continued to label ASEAN as a "military alliance". It pointed to the suggestion in ASEAN for the joint production of anmunition with American assistance and to Indonesian Defence Minister Panggabean's suggestion that ASEAN air forces be standardised with the F-5. It quoted the several bilateral military agreements that tied the countries together: those between Thailand and Malaysia for border operations and those between Malaysia, Indonesia and the Philippines for border security and suppression or piracy. (Sotsialisticheskaya Industriya, 13 September 1977, 3, in FBIS Soviet Union Daily Report, 19 September 1977. K1-K2). Moscow also alleged that the American Seventh Fleet had been used to influence the outcome of the Bali summit in 1976 and the foreign ministers' meeting in 1977 by way of putting American pressures on ASEAN leaders (Radio Moscow Indonesia. 21 February 1977, in FBIS Sovict Union Duily Report, 2 March 1979. K1). The Soviet Union further referred to the Australian and New Zealand provision of military equipment and training, stating that it linked ASE.AN with the ANZUS pact. Moscow classified ASEAN as a component of the US-Pacific Doctrine announced by President Nixon. 
Prior to the signing of the twenty-five year treaty with Moscow in November 1978 and the invasion of Kampuchea in the following month, Hanoi had reduced its hostility to ASEAN and appeared keen to pursue the ZOPFAN proposal. There were visits to ASEAN capitals, offers of non-aggression treaties, and calls for constructive relations between Vietnam and ASEAN states: all part of Hanoi's 'peace offensive'. If Malaysia and Singapore were initially encouraged by this approach and were even prepared to view Hanoi's treaty with Moscow with less scepticism, the Vietnamese strike across the border into Kampuchea profoundly alarmed them; ${ }^{7}$ it certainly strengthened the misgivings of Singapore and Thailand with regard to Vietnam's intentions in the area. ${ }^{8}$

A second period in ASEAN-Vietnam relations began with the Christmas Day 1978 Vietnamese invasion of Kampuchea and the Chinese 'punishment' raid on Vietnam that followed. Vietnam's attitude towards ASEAN was influenced by the events in Kampuchea and by the relations between Vietnam and China.

\footnotetext{
${ }^{7}$ The train of events prior to Hanoi's decision to invade Kampuchea provides circumstantial evidence that the invasion had been planned by the Vietnamese Communist Party Central Committee (FEER, 22 February 1979, 33). As Vietnam made its diplomatic overtures to re-assure ASEAN states of its peaceful intentions, Hanoi had been stealthily working towards realising its plan. This included the establishment of closer economic and military ties with the Soviet Union, a gradual escalation of its military strength along the Vietnam-Kampuchea border and the creation on 2 December 1978 of the Kampuchea National United Front for National Salvation. Vietnam had concluded, despite the US-Japan-China axis, that the US would not react to its action in Kampuchea; it miscalculated how far Beijing would go to save the regime of Pol Pot. Vietnam perhaps expected the ASEAN states to view the incorporation of Kampuchea within the Vietnamese sphere of influence 'as a special case without prejudice to future relations between them and the government in Hanoi'. M. Leifer, Conflict and Regional Order in Southeast Asia, Adelphi Paper No.162 (London: International Institute for Strategic Studies, 1980), 26.

singapore acted on the assumption that Vietnam and Kampuchea were indeed the respective proxies of the Soviet Union and China. In Thailand, political thought on the issue was divided. A. Suhkre. "Thai-Vietnamese Relations and Large Power Conflicts in Asia" (Rio de Janeiro, August 1982), 2-15. One school felt that the Kampuchean conflict was part of a broader Soviet-Vietnamese design to further their influence in the region. But even within the school there was indecision as to whether Thailand should align itself with China and the United States in calling for a Vietnamese withdrawa from Kampuchea or keep a posture that would not be seen by Hanoi to be too heavily influenced by China's hostility towards Vietnam (reflecting some apprehension in Thailand on the extent China could be relied upon as a 'friend'). The second school believed that the invasion was simply a consequence of the long standing hostility in Khmer-Vietnamese relations; this view tended to be sympathetic to the Vietnamese difficulties with Kampuchea under Pol Pot's reign. This school encouraged Bangkok to pursue a policy of neutrality and equidistance in respect of the conflict in Kampuchea.
} 
To the extent that ASEAN involved itself in supporting the anti-Heng Samrin forces and gave the impression of being aligned with China on the issue, Vietnam's opposition was intransigent.

Relations deteriorated further and ASEAN's suspicions were deepened by the massive exodus of refugees.'Huge numbers fled Kampuchea with the breakdown of Khmer Rouge control and there was a large and steadily increasing flow into Thailand from Laos. The flow of boat refugees from Vietnam reached a crescendo between 1979 and 1980 affecting all the ASEAN states. It was the boat refugees, largely ethnic Chinese, whose departure from Vietnam was officially encouraged at high levels, which ASEAN states found unforgivable and which roused ASEAN fears of a deliberate Vietnamese attempt at political, social and economic destabilisation of their countries.

Vietnam had not expected the offensive against Kampuchea to last more than one dry season, and in any case expected ASEAN states to value Vietnam's friendship sufficiently to treat the invasion of Kampuchea as a bilateral issue between Hanoi and Phnom Penh. Vietnam's invasion can be seen as a modern continuation of hundreds of years of alternate Thai and Vietnamese encroachments on Khmer territory and independence. In this context, the self-defeating nationalism of Pol Pot is more comprehensible, while Vietnam saw the necessity of its action in terms of the defence of its own security. The early Kampuchean insistence on pursuing an independent foreign policy, Pol Pot's purges of Khmer Rouge cadres with Vietnamese links, his help to South Vietnamese dissidents resisting Hanoi's unification programme, the Khmer Rouge assertion in 1977 that the principal enemy of Kampuchea was Vietnam, the attacks from September that year on Vietnam's border provinces, and the huge flow of Khmer and ethnic Vietnamese Kampucheans into Vietnam from Kampuchea, were essential elements in Vietnam's feelings of insecurity.

For ASEAN and particularly for Thailand, the invasion of Kampuchea meant the loss of a buffer state against the Vietnamese and a shift in the regional power balance. ${ }^{9}$ In re-

\footnotetext{
${ }^{4}$ For Singapore. it was a confirmation of its long standing suspicion that Vietnamese pledges of peaceful intentions could not be trusted. As one of the island's dailies observed:

"Vietnam's part in contriving the fall of Phnom Penh deserves the universal condem-
} 
sponse. ASFAN argued that to surrender the fight against the violation of territorial sovereignty was to condone a repetition in Southeast $\Lambda$ sia of Soviet actions in Hungary and crechoslovakia, and later in Afghanistan and Poland. To that extent, the ASEAN states took sides with the ousted Pol Pot regime. The latter claimed that Vietnam had been determined to destroy the independent political line of the Kampuchean Communist Party from 1970 to 1975 , and in the years following to subvert Kampuchean independence.

It was Thailand's leaning towards China (while regarding Beijing as a threat) that heightened Vietnam's concern at the ASEAN stand on Kampuchea. For Vietnam, it was China and not ASEAN which was the dangerous enemy. China's close support of the hostile Pol Pot regime was to Vietnam a threat of 'encirclement', and this was a factor in the Third Indochina War. In the White Book (which does not fail to acknowledge China's past aid to the cause of Vietnamese nationalism), Hanoi alleges that Mao Zedong betrayed the Vietnamese struggle by trying to maintain a divided Vietnam. It was China's policy not to permit Vietnam the exercise of unchallenged supremacy in Indochina. The Chinese road building activities in north-western Laos, their support for Prince Norodom Sihanouk's government-in-exile, and the cultivation of the new Khmer Rouge leaders in Phnom Penh, were, in Vietnamese eyes, examples of this policy.

China also demanded that Vietnam declare its support for either China or the Soviet Union. Vietnam, wishing to maintain neutrality in the Sino-Soviet rivalry, was unwilling to condemn the Soviet Union. This added strain to the Hanoi-Beijing relationship. The fall of the Gang of Four encouraged Hanoi to believe that the new leadership in Beijing would be pragmatic, but the stream of Vietnamese visits to the Chinese capital produced no

nation of the world community, though with its Soviet ally at the United Nations nothing more than pious declarations are likely to be passed. For the region, this is not good enough, because the question uppermost in ASEAN governments must be: How far, territorially and ideologically, are the Vietnamese prepared to go? And even if they do not go beyond the establishment of an Indochina under Hanoi's sway, the balance of forces regionally would have already been tipped in favour of the Moscow-

Hanoi axis" (New Straits Times, 9 January 1979, editorial). 
softening in the Chinese attitude. In February 1977, China cut off further economic aid to Vietnam and denounced Vietnam in the Chinese media.

Thereafter, and particularly after the 'Chinese lesson' of February 1979, Hanoi found itself menaced by Chinese armies poised on the northern frontiers, and Chinese-supported Khmer Rouge soldiers continuing to fight against the Vietnamese forces in Kampuchea. The close relationship between China and the Khmer Rouge was a thorn in Vietnam's flesh. ASEAN's pronouncements were seen by Vietnam to align it with China, ${ }^{10}$ while Thailand went beyond diplomatic castigation of Vietnam to physical assistance in maintaining the Chinese supply line to the Khmer Rouge, and in providing them with sanctuary.

ASEAN tried to avoid the hardline Chinese policy towards Vietnam, particularly at the International Conference on Kampuchea in July 1981. Its success was however limited. At the same time, ASEAN member states remained divided on the crucial issue of which country, Vietnam or China, posed the greater threat to their medium and long-term security. Upon the answer to that question depended an appropriate policy towards the contending parties, but ambiguity and ambivalence dominated effort at regional assessment.

Indonesia's view of a solution to the Kampuchean impasse was guided in part by Vietnamese criticism of Jakarta's East Timor policy, ${ }^{11}$ but more importantly by the fear that it was China rather than Vietnam that posed the principal long term security threat. Jakarta respected the determined nationalism

\footnotetext{
10 When the Chinese launched their 17-day punitive drive against the Vietnamese beginning on 17 February 1979, the ASEAN countries found themselves duty bound by their neutrality to issue a statement condemning both parties. ASEAN called for the removal of all foreign troops from Indochina (meaning both Vietnamese and Chinese). Singapore's Premier Lee Kuan Yew stated at that time: "Our dilemma is acute. If there had been no [Chinese] intervention, we would face Vietnamese supremacy which in this case means Soviet supremacy. If the intervention is over-successful, it means that in ten, fifteen years there will be an assertion of influence, perhaps not amounting to hegemony, by a Conmunist power that has influence over all guerrilla movements in the countries of Thailand, Malaysia, Singapore and Indonesia" (Singapore Bulletin, August 1979).

"Vietnam made scathing attacks on critics of the country's military role in Kampuchea by referring to the 'occupation' of East Timor by Indonesian troops since 1976 (Indonesian Times, 12 February 1981, 1, 2).
} 
of Vietnam and so was prepared to believe that Hanoi did not entertain any expansionist desires beyond Indochina. Secondly, Jakarta believed that Vietnam's military strength, its fiercely independent spirit, and its revolutionary fervour made it a singularly effective bulwark against China, and this could counterbalance any Chinese desire to regard Southeast Asia as its natural sphere of influence. Jakarta's apprehension of China had been aroused by the assistance Japan and the United States offered China, after the signing of the Sino-Japanese Treaty of Peace and Friendship in August 1978, to increase Chinese military capability.

However, Jakarta's fairly consistent favourable view of Vietnam's intentions became more ambivalent by the end of 1978 with Vietnam's entry into a treaty relationship with the Soviet Union, its invasion of Kampuchea and the resulting pressure on Thailand from the refugee influx. Indonesia's priority in the circumstances was to recognise the interests of its ASEAN partner and adhere to ASEAN's position. Jakarta had to respect the agreement within the group that the common policy should be to support the concerns of the frontline state. Even so, Jakarta kept communications with Hanoi open. It also tried, despite ASEAN diplomatic support for Democratic Kampuchea, to distance itself from the ousted regime. For instance, when Ieng Sary arrived in Jakarta in November 1980 to attend a ministerial conference of the Colombo Plan, he was only permitted brief and ceremonial meetings with the Indonesian Foreign Minister and the President. Jakarta also announced the closure of its Kampuchean watching station in Bangkok, set up in April 1975 after its mission in Phnom Penh was evacuated. In addition, Thailand's involvement with China in support of the Khmer Rouge was viewed in Jakarta as an obstacle to ASEAN reaching a diplomatic settlement with Vietnam.

Malaysia shared Indonesia's general sentiments on Vietnam and Kampuchea, and its distrust of China. ${ }^{12}$ Malaysian distrust

\footnotetext{
${ }^{12} \ln$ March 1980, Chinese Foreign Minister Huang Ho paid a visit to the Philippines, Malaysia and Singapore on an anti-Vietnam and anti-Soviet diplomatic drive. Though he seemed to have had a fairly receptive audience in Manila and Singapore, the reaction in Kuala Lumpur was somewhat cool; the Malaysian Foreign Minister did not go beyond stating the hope that China would play a positive role in bringing about a political settlement in Kanipuchea; he avoided any close aseociation with Huang's standpoint (FEER, 28 March 1980, 15).
} 
of China arose largely from two sources. The first was China's insistence on separating government-to-government from partyto-party relations and in particular its suspected continuing support for the banned Communist Party of Malaya. Malaysia’s suspicion on this point was justified when China promised to discontinue broadcasts of the Voice of the Malayan Revolution on 30 June 1981, only to open another clandestine radio station, the Voice of Malayan Democracy, the following day. The second was Beijing's determination to bleed Vietnam by a strategy aimed at maintaining the crisis in Kampuchea rather than resolving it.

On the other hand, Malaysia felt that there were two advantages to be gained by ensuring a viable rather than weak Vietnam. Firstly, a strong Vietnam would have less need to be unduly reliant on the Soviet Union. Secondly, a strong Vietnam would discourage China from seeing Southeast Asia as a backyard for the spread of its influence.

In the Malaysian view, a strong Vietnam did not mean that Vietnam should totally dominate Indochina. What it implied was that Kuala Lumpur would not have been averse to the Vietnamese exercising loose political influence over Indochina. Malaysia's major objection to Vietnam's Kampuchea policy was Vietnam's invasion of Kampuchea, its gross violation of Kampuchean sovereignty and its installation of the Heng Samrin regime, a regime that Malaysia was not prepared to recognise. It is tempting to speculate that had Hanoi, without invading or occupying Kampuchea, been able to engineer Pol Pot's replacement by a government aligned with Hanoi (especially in foreign policy), the reaction of Malaysia (and some other ASEAN states) might have been somewhat different.

Despite the contribution of the Philippines Foreign Minister Carlos Romulo, who acted as spokesman for ASEAN, the Philippines was the 'odd man' in ASEAN for its low profile on the Indochina question. Nevertheless, the Philippines' position on most issues was generally close to that of Indonesia and Malaysia.

Singapore's view, influenced by its size and vulnerability, was dominated by suspicions of sinister motives in Moscow, 
Beyng and Hanoi. Singapore interpreted the Third Indochina War as a proxy war between the Soviet Union and Chma, each manipulatıng its smaller ally, with the (hinese prepared to fight to the last Kampuchean and the Soviets prepared to fight to the last Vietnamese. But between China and the Soviet Union, it was the Soviet Union that Singapore most feared despite the fact that, for various internal and other reasons, Singapore withheld diplomatic representation in Beijing. Whether Soviet policies were primarily intended to serve expansionist goals or to counter the influence of China, Singapore saw the presence of nearly 180,000 Vietnamese troops in Kampuchea, 50,000 in Laos, several thousand Soviet technicians in the three countries of Indochina, and Soviet naval and air force access to Southeast Asia from Vietnamese bases, as an attempt to increase Soviet leverage in Southeast Asia.

Thus it was Singapore's consistent policy that the regional order is best managed by balancing the strength of the super powers; in this context, Singapore - stridently anti-communist - favoured a strong American military presence as neutralising Sino-Soviet rivalry in the region.

Thailand took the position that the principal threat to its stability and security was Vietnam, a traditional enemy. Vietnam was not likely to forgive Thailand for having acted as a close ally of the United States during the Second Indochina War. Thailand could not overlook that Vietnam, with a battle-hardened army which was the fourth largest in the world, was a mighty military machine that could do immense harm. ${ }^{13}$ With Vietnam's invasion of Kampuchea, there was no longer a buffer between Thailand and Vietnam's military might. Huge numbers of Khmer refugees fled from fighting and starvation in Kampuchea, and with them came the remnants of the Khmer Rouge and other anti-Vietnamese resistance fighters. Thailand was inevitably drawn into the Vietnamese-Kampuchean conflict and it support-

13Vietnam's army outnumbered that of Thailand by four times; it had 900 Soviet built 's 150 Korcan vintage M-14s (an equal number of British Scorpion reconnassance vehicles had already been ordered). Vietnam had twice the air capability that Thailand possessed. The Thai strategic defence sectors, such as the Wathatokern P.ss at Aranyaprathet, had heen virtually neglected as long as Kampuchea had prosided a 'buffer'. 
ed the resistance fighters. In June 1980, with the support of the United Nations High Commissioner for Refugees, Bangkok inaugurated a policy of voluntary repatriation of Kampuchean refugees from camps in Thailand. Vietnam rejected this policy, and emphasised its objections by violating Thai territory with incursions across the border.

In Bangkok's geopolitical appraisals, any dependence upon ASEAN to counter Vietnam had to be a limited one. It knew that it could count on the moral and diplomatic support of its ASEAN partners. As Thailand was the frontline state, ASEAN members had agreed to take Thailand's lead in matters pertaining to Vietnam. It was even possible that the other ASEAN states would support Thailand to the extent of sending troops to defend Thailand, if such a step became necessary. However, Thailand was aware that the combined military strength of ASEAN states was negligible compared to that of Vietnam and that diplomatic deterrence was not in itself sufficient to discourage Hanoi.

Hence, Thailand oriented its policy towards the United States and China. In early 1979, the United States reaffirmed its commitment to Thailand under the Manila pact of September 1954, and undertook to accelerate the transfer of arms to Thailand. Bangkok saw Beijing as the most effective deterrent to Vietnamese military intransigence. So, while declaring itself neutral, Thailand was prepared to risk incurring Vietnam's wrath by allowing Chinese military supplies for the Khmer Rouge to pass through Thai territory and to offer sanctuary to Khmer resistance fighters. ${ }^{14}$ But to give effect to the official policy of neutrality, Thai Premier Kriangsak visited Moscow in March 1979 and (for a time) conditionally allowed Soviet transport aircraft to fly over Thailand to Indochina.

\footnotetext{
${ }^{14}$ Despite official denials, Thailand, willing or under pressure, permitted China to supply facilities to the insurgent forces in Kanpuchea through Thai ports of entry; supplies were transported overland from the ports to bases used by Pol Pot loyalists in the Cardamom mountains in southwest Kampuchea. Though the evidence for this was at first lacking. Chinese Vice-Premier Deng Xiaoping, who was in the United States shortly before Kriangsak's arrival, had publicly stated that Beijing had been supplying arms and ammunition to Pol Pot's resistance forces through Thailand (FEER, 16 February 1979, 29). The scale of these operations was however in doubt; Thailand must have been aware of the dangers of antagonising the Vietnamese who were moving closer to the eastern border of Thailand. But with the Vietnamese-Kampuchean struggle at Thailand's doorstep, Bangkok had good reason to feel that diplomacy had failed; the maintenance of strict neutrality was felt to be difficult.
} 
The continuing high level of Vietnam's presence in Kampuchea and the Khmer refugee outflow hardened Thai attitudes towards Hanoi and Moscow. In addition, Thailand was heartened by the 'Chinese lesson' of February 1979 and by the efforts of the Khmer resistance and believed that time was on the Kampuchean side so long as the international community refused to accept a Vietnamese fait accompli in Kampuchea.

Yet Bangkok was sensitive to the apprehension with which other ASEAN capitals viewed Beijing. The pressure from ASEAN and the opinion expressed by sections of the Thai community that China might be glad to see Thailand at war with Vietnam, did have a cautioning effect on the Thai government. But it refused to accept the loss of Kampuchea as a buffer against Vietnam, or the argument that a strong Vietnam was necessary to act as a buffer against China.

As stated earlier, one of Vietnam's strategies was to keep ASEAN opposition to its Kampuchean policy off balance and on the defensive. This strategy was pursued by maintaining an appearance of flexibility. It consisted of offering ASEAN a variety of proposals which Vietnam knew to be unacceptable to ASEAN. A few illustrations of this argument can be drawn.

The first was Vietnam's proposal in June 1978 to create a 'zone of peace, independence and neutrality' as opposed to ASEAN's call of a zone of 'peace, freedom and neutrality'. Made at a time of mounting tension with Kampuchea and China, the Hanoi proposal was designed to catch offguard the foreign ministers who were gathered at Pattaya for an official meeting. Vietnam's proposal opened a door for negotiations and gave the impression that Vietnam supported the concept of a zone of peace but disagreed only on the details. ${ }^{15}$

\footnotetext{
${ }^{15}$ To further reinforce Vietnam's show of friendship to ASEAN, Vice Foreign Minister Phan Hien paid a visit to Malaysia, Singapore and Thailand at the end of July 1978. The most significant aspect of that visit was the Vietnamese declaration that Hanoi was now prepared to shelve its proposal for a Southea:t Asian zone of peace that included the term 'independence' in favour of discussing the original Malaysian-inspired concept of ZOPFAN. But ASEAN capitals, particularly Singapore, were suspicious that the new offer from Hanoi was being made at the request of Moscow. Phan Hien's proposal came at a sensitive point in Beijing-H tanoi relations which made it an inappropriate time to respond. The Vietnamese visit to the three ASEAN states therefore did not produce any conclusive results (FEER, 4 August 1978, 10).
} 
The second occasion was in September 1978 when Vietnam offered to sign bilateral treaties of friendship and non-aggression with ASEAN states. There had been no previous diplomatic initiatives on which such treaties could be built and ASEAN was suspicious of the breakdown of its collective approach implicit in such an offer. However the offer was repeated in January 1980 along with a repetition of the proposal for a 'zone of peace, independence and neutrality'. Vietnam was perhaps trying to wean ASEAN away from its close relationship with Beijing, but ASEAN again rejected the proposals fearing that to support them would have constituted tacit endorsement of the Heng Samrin regime in Kampuchea. ${ }^{16}$

A third occasion on which Vietnam put up counter-proposals unacceptable to ASEAN followed upon Vietnam's rejection in mid-June 1980 of the Thai proposal for voluntary repatriation of Kampuchean refugees. As well as reiterating the zone and treaty proposals, Vietnam made a number of significant new proposals. These included the establishment of a demilitarised zone on the Thai-Kampuchean border, the setting up of a joint commission to implement agreements guaranteeing peace and stability, the establishment of refugee camps far away from the border, the disarming of the Khmer Rouge and Khmer Serei who had taken refuge in Thailand and the distribution of humanitarian aid on Kampuchean rather than on Thai territory. Thailand rejected the zone as proposed, arguing that Kampucheans would be prevented from returning to their homeland; it proposed instead a zone under UN supervision, but this was rejected by Vietnam on the grounds that the UN could not be regarded as neutral while the Khmer Rouge was represented in its General Assembly. However, Vietnam was keen to appear conciliatory in view of the debate on the United Nations on Kampuchea in September 1980.

A fourth example of Vietnam's tactics was its announcement in September 1980 that it was willing to withdraw part of its forces from Kampuchea if a demilitarized zone along the border was set up or if Thailand undertook to respect the sovereignty of Kampuchea within the current border. Vietnam at various

\footnotetext{
${ }^{16}$ K.K. Nair, ASEAN-Indochina Relations Since 1975: The Politics of Accommodation (Canberra: Australian National University, 1984), 101-103.
} 
stages did claim to have withdrawn unspecified numbers of soldiers and it has been suggested here that this did not signify a shift in Vietnamese policy. In fact such withdrawals might have been no more than a rotation of Vietnamese infantry within Kampuchea. In any case, Vietnam tried to temper its insistence on the "irreversibility' of the Kampuchean situation with announcements of troop withdrawals even when the pre-condition for such withdrawals had not been met by ASEAN states. ${ }^{17}$ This was sound diplomacy.

A fifth illustration of the Vietnamese plan to keep ASEAN diplomatically off balance was in 1981 when Vietnam rejected the idea of a United Nations International Conference on Kampuchea scheduled for July that year, and counter proposed a regional conference between the Indochinese and ASEAN states. This suggestion was made just prior to the start of the 1981 Non-aligned Conference in New Delhi; Hanoi intended to influence the outcome of debate there by appearing reasonable and conciliatory. But predictably ASEAN turned down the proposal for a number of reasons, the principal one being that Vietnam was not prepared to discuss at the regional conference the question of Kampuchea but only the policies of China.

Alongside Vietnam's strategy of apparent conciliation was a bellicosity designed to pressure ASEAN states into acceptance of the status quo in Kampuchea. The expulsion of ethnic Chinese from Vietnam might have been motivated by internal factors, particularly a need to divest Vietnam of an urban middle class that was felt to be an implacable enemy (the precedent for this being Fidel Castro's policy of allowing middle class Cubans to seek refuge in Florida). Vietnam might have even underestimated the effect of this policy on the region.

\footnotetext{
${ }^{17}$ The offer looked attractive in a situation that seemed otherwise intractable to ASF.AN diplomatic initiatives. Moreover, some countries, including India, had shifted towards recognition of the Heng Samurin regime. Singapore, in a campaign to canvass votes for ASEAN at the UN, made its view of Hanoi's foreign policy clear in a 52-page booklet From Plinom Pchh to Kahul, said to have been authored by the country's Foreign Minister S. Rajaratnam (FEER, 3 October 1980, 19) and distributed to UN delegates. The need for a nore vigorous campaign that year at the United Nations (compared to the previous one) suggested that votes in favour of seating the incumbent Democratic Kampuchea delegation were more difficult to obtain. When the General Assembly's credentials committee agreed to recognise the representation of Democratic Kampuchea on 18 September 1980, the votes still showed a comfortable margin but public pressure on Western and other governments to de-recognise Pol Pot had been growing to an extent which could not be ignored.
} 
But there is little to suggest that Vietnam was displeased with any socio-economic destabilization that ASEAN feared from the refugee influx. When Premier Pham Van Dong undertook a tour of the ASEAN capitals in September and October 1978 he noted that Vietnam recognised the strains imposed on its neighbours by the refugee exodus and indicated it would do its best to alleviate the situation. However, the numbers of refugees coming into ASEAN states continued to rise sharply in the first half of 1979. Vietnam denied, prior to the UN Conference on the matter in Geneva in July 1979, any responsibility for the outflow of the boat people but later agreed to halt illegal departures. A second similar resort to force to make a point was Vietnam's violation of Thai territorial sovereignty in June 1980 to register Hanoi's disapproval of Bangkok's support to the Khmer Rouge and Thailand's foreign policy tilt towards the Chinese. Since then, there have been further incidents on the Thai-Kampuchean frontier.

ASEAN's refusal to yield to a fait accompli in Kampuchea was effectively expressed in its refusal to be compromised by limited Vietnamese concessions, intensification of diplomatic activity in the United Nations and active involvement in the establishment of a Third Force to fight the Vietnamese in Kampuchea. A negotiated settlement of the Kampuchea situation between ASEAN and Vietnam is doubtful as long as Hanoi maintains its forces in Kampuchea. In an interview with Democratic Kampuchea Premier Son Sann, held in New Zealand in mid-May 1983 , the present writer was informed that Vietnam had an enormous 'colonisation' program in Kampuchea. According to Son Sann, the Heng Samrin administration had decreed in 1981 that up to 500,000 Vietnamese families be settled in Phnom Penh and two southern Kampuchean provinces. If this is true, it does point to a reluctance in Hanoi to withdraw its presence from Kampuchea. It can be assumed that Hanoi is likely to insist on its military presence in Kampuchea for as long as it sees the Chinese as supporting the Khmer resistance forces.

In the circumstances, it would appear that there can be only one factor that would have a profound effect upon the stalemate in Kampuchea. This would be the result of the on-going negotiations between Moscow and Beijing for the normalization of relations between the two major powers. During the first 
round of these talks in Beijing in October 1982, it is believed that China proposed, amongst other items, that the Soviet Union halt its assitance to Vietnam in Kampuchea and use its good offices to persuade the Vietnamese to withdraw troops from Kampuchea.

The question is whether the Soviet Union would want to press Vietnam to make concessions to China. The Soviet presence in Vietnam is helped by the fact that it is Vietnam that needs Soviet assistance against China and the Khmer Rouge. Similarly, Vietnam's presence in Kampuchea is justified by the continuing insurrection in Kampuchea; from that point of view it would not be in Vietnam's interests to wipe out the Khmer Rouge, even if Hanoi could achieve it. A major reason why the Soviet Union would apply pressure on Vietnam to accomodate China would be if the Soviet Union felt that a Moscow-Beijing compromise would be rewarding. However, Vietnam would have to have good reason to submit to Soviet pressure. Thus, it would appear that a negotiated settlement of the Kampuchean issue is not likely to be achieved in the immediate future. 